\title{
Rosoxacin in the treatment of uncomplicated gonorrhoea in men
}

\author{
KANCHANA PANIKABUTRA, CHARAS ARIYARIT, ANUPONG CHITWARAKORN, \\ AND CHOOSAK SAENSANOH \\ From the VD Control Division, Bangrak Hospital, Bangkok, Thailand
}

SUMMARY Between 3 January and 4 March 1983 we treated 200 male patients diagnosed as having uncomplicated gonococcal urethritis with one of two regimens. They were divided into two groups and randomly assigned to treatment with either $2 \mathrm{~g}$ spectinomycin administered intramuscularly (group A) or $300 \mathrm{mg}$ rosoxacin by mouth (group B). Of 187 isolates tested for the production of $\beta$-lactamase, $101(54 \%)$ were penicillinase producing Neisseria, gonorrhoeae (PPNG) strains. All 81 cases followed in group A (spectinomycin) were cured, compared with $88.5 \%$ ( 77 out of 87 ) of the patients followed in group B (rosoxacin).

We concluded that rosoxacin at a dosage of $300 \mathrm{mg}$ administered orally was fairly effective in the treatment of gonococcal urethritis in men caused by both PPNG and non-PPNG strains.

\section{Introduction}

Since the emergence of penicillinase producing Neisseria gonorrhoeae (PPNG) strains in 1976, penicillin is no longer the drug of choice in the treatment of gonorrhoea. ${ }^{1}$ After the first two cases of PPNG in Bangkok were reported in 1977, the failure rates in the treatment of uncomplicated gonorrhoea with penicillin increased until a failure rate of $30 \%$ was reached in 1979. ${ }^{3}$ PPNG strains account for a large proportion of all gonococcal isolates in Thailand. In $198142 \cdot 9 \%-48 \cdot 9 \%$ of strains of $N$ gonorrhoeae isolated in Bangkok were reported to be PPNG. ${ }^{45}$

Although spectinomycin is the drug that produces acceptable cure rates in and is recommended in the treatment of gonorrhoea caused by PPNG strains, we need to find an alternative treatment. ${ }^{4-8}$ Since 1981 PPNG strains resistant to spectinomycin have been reported in many parts of the world. ${ }^{9-13}$ The in vitro activity of rosoxacin, a pyridyl quinolone derivative, against $\boldsymbol{N}$ gonorrhoeae has been studied and shown to be more active than penicillin, cefuroxime, and tetracycline. Its activity was not affected by the production of $\beta$-lactamase. ${ }^{14} \mathrm{We}$ undertook this study to compare the efficacy of rosoxacin and spectinomycin in the treatment of uncomplicated gonorrhoea in men.

Address for reprints: Dr K Panikabutra, VD Control Division, Bangrak Hospital, 189 South Sathorn Road, Bangkok 10120, Thailand

Accepted for publication 10 February 1984

\section{Patients and methods}

\section{STUDY DESIGN}

Men attending this hospital between 3 January and 4 March 1983 who were diagnosed as having uncomplicated gonorrhoea with a positive smear on the initial visit were selected. The study comprised 200 men, all of whom were Thai. They were divided into two groups and randomly assigned to treatment with either $2 \mathrm{~g}$ spectinomycin administered intramuscularly (group A) or $\mathbf{3 0 0} \mathrm{mg}$ rosoxacin by mouth (group B).

\section{DIAGNOSTIC METHODS}

The diagnosis was based on the finding of Gram negative intracellular diplococci in the Gram's stained smears and on the results of cultures of specimens taken from the urethra. Blood for routine serological tests for syphilis was taken in every case. The Gram's stained smears were examined in the clinic; the other specimens were inoculated direct on to Thayer-Martin medium and incubated at $35^{\circ} \mathrm{C}$ in an atmosphere of carbon dioxide. Cultures were examined after 24 and $\mathbf{4 8}$ hours, and a diagnosis of gonorrhoea was based on typical colonial morphology, Gram's stained smear microscopy showing Gram negative diplococci, and a positive oxidase test. Isolates were confirmed as gonococci by sugar fermentation reactions. The colonies were subcultured to identify PPNG by the cephalosporin test. ${ }^{15}$ The confirmed gonococcal isolates were tested for antibiotic sensitivity by agar plate dilution techniques. ${ }^{16}$ 
FOLLOW UP

Follow up visits were arranged three, seven, and 14 days after treatment. Urethral specimens for Gram's stained smear microscopy and culture were taken on each occasion. Routine serological tests for syphilis were performed at monthly intervals for three months.

If gonococci persisted or reappeared within 14 days of treatment and further sexual intercourse was denied by the patient, then the treatment was considered to have failed. The reappearance of gonococci after 14 days, irrespective of the patient's history, was considered to be due to reinfection. Those who admitted sexual intercourse before the first follow up examination were excluded from the final assessment.

Patients with microscopical or culture evidence of gonococcal infection at the follow up visits were treated with spectinomycin $2 \mathrm{~g}$ administered intramuscularly. Those who at day 7 had signs of urethritis $(\geqslant 4$ polymorphonuclear lencocytes/1000 $\times$ microscope field of Gram stained smear) but no evidence of $\boldsymbol{N}$ gonorrhoeae were considered to have postgonococcal urethritis (PGU). ${ }^{17}$

STATISTICAL ANALYSIS

The unpaired $t$ test and the $\chi^{2}$ test were used.

\section{Results}

Of the 200 patients enrolled in the study, 32 were excluded; 11 because $N$ gonorrhoeae did not grow in the initial culture, four because the patients had sexual intercourse before the first follow up examination, and 17 because the patients defaulted after the treatment. Of 189 isolates, 187 were tested for $\beta$-lactamase production: $101(54 \%)$ gave positive results. There were 81 patients in group $A$ and 87 in group B. Table I shows the results of treatment.

TABLE I Results of treatment of gonorrhoea with spectinomycin or rosoxacin

\begin{tabular}{llllll}
\hline & \multicolumn{2}{l}{$\begin{array}{l}\text { Group } \text { A } \\
\text { (spectinomycin) }\end{array}$} & & \multicolumn{2}{l}{$\begin{array}{l}\text { Group B } \\
\text { (rosoxacin) }\end{array}$} \\
\cline { 2 - 3 } \cline { 5 - 6 } & $\begin{array}{l}\text { No } \\
\text { assessed }\end{array}$ & $\begin{array}{l}\text { No } \\
\text { cured }\end{array}$ & & $\begin{array}{l}\text { No } \\
\text { assessed }\end{array}$ & $\begin{array}{l}\text { No } \\
\text { cured }\end{array}$ \\
\hline PPNG strains & 46 & 46 & 45 & 40 \\
Non-PPNG strains & 34 & 34 & 41 & 36 \\
Not tested & 1 & 1 & 1 & 1 \\
Total & 81 & 81 & 87 & 77 \\
& & $(100 \%)$ & & $(88.5 \%)$ \\
\hline
\end{tabular}

PPNG = penicillinase producing Neisseria gonorrhoeae .

SENSITIVITY OF N GONORRHOEAE TO

ANTIBIOTICS

Table II shows the minimum inhibitory concentrations (MICs) of spectinomycin and rosoxacin for
TABLE II Sensitivity of $N$ gonorrhoeae to antibiotics

\begin{tabular}{|c|c|c|c|c|}
\hline \multirow[b]{2}{*}{$M I C s(m g / l)$} & \multicolumn{2}{|c|}{$\begin{array}{l}\text { Group A } \\
\text { (spectinomycin) }\end{array}$} & \multicolumn{2}{|c|}{$\begin{array}{l}\text { Group B } \\
\text { (rosoxacin) }\end{array}$} \\
\hline & $P P N G$ & $\begin{array}{l}\text { Non- } \\
\text { PPNG }\end{array}$ & PPNG & $\begin{array}{l}\text { Non- } \\
\text { PPNG }\end{array}$ \\
\hline 0.00001 & & & & 2 \\
\hline 0.00002 & & & 1 & \\
\hline 0.00005 & & & 2 & 2 \\
\hline 0.0001 & & & 3 & 3 \\
\hline 0.0002 & & & 2 & 2 \\
\hline 0.0005 & & & 7 & 6 \\
\hline 0.001 & & & 8 & 5 \\
\hline 0.002 & & & 5 & 7 \\
\hline 0.005 & & & 8 & 12 \\
\hline 0.008 & & & 7 & 5 \\
\hline 0.01 & & & 19 & 15 \\
\hline 0.03 & & & 31 & 19 \\
\hline 0.06 & & & & 1 \\
\hline$>0.06$ & & & 8 & 7 \\
\hline $5 \cdot 0$ & 21 & 22 & & \\
\hline $7 \cdot 5$ & 49 & 27 & & \\
\hline $10 \cdot 0$ & 25 & 32 & & \\
\hline $15 \cdot 0$ & 6 & 5 & & \\
\hline Total & 101 & 86 & 101 & 86 \\
\hline Mean MIC & $8 \cdot 04$ & $8 \cdot 23$ & 0.0133 & 0.0114 \\
\hline
\end{tabular}

PPNG = penicillinase producing Neisseria gonorrhoeae.

PPNG and non-PPNG strains. The difference between the MICs of either drug for PPNG and for non-PPNG strains was not significant. The mean MIC of spectinomycin was $8.04 \mathrm{mg} / 1$ for PPNG strains and $8.23 \mathrm{mg} / \mathrm{l}$ for non-PPNG strains $(t=$ $0.4917 ; p>0.05)$. The mean MIC of rosoxacin was $0.0133 \mathrm{mg} / \mathrm{l}$ for PPNG strains and $0.0114 \mathrm{mg} / 1$ for non-PPNG strains $(t=0.5521 ; \mathrm{p}>0.05)$.

Table III shows the correlation between the MICs and the results of treatment with rosoxacin. Of the 41 patients infected with PPNG strains whose MICs ranged from $0.00002 \mathrm{mg} / \mathrm{l}$ to $0.03 \mathrm{mg} / \mathrm{l}, 37(90 \%)$

TABLE III Correlation between the MICs and the results of treatment with rosoxacin (group B)

\begin{tabular}{|c|c|c|c|c|}
\hline \multirow{2}{*}{$\begin{array}{l}\text { MICs of } \\
\text { rosoxacin } \\
(\mathrm{mg} / \mathrm{l})\end{array}$} & \multicolumn{2}{|l|}{$P P N G$} & \multicolumn{2}{|c|}{ Non-PPNG } \\
\hline & Cured & Not cured & Cured & Not Cured \\
\hline $\begin{array}{l}0.00001 \\
0.00002 \\
0.00005 \\
0.0001 \\
0.0002 \\
0.0005 \\
0.001 \\
0.002 \\
0.005 \\
0.008 \\
0.01 \\
0.03 \\
0.06 \\
>0.06 \\
\\
\text { Total }\end{array}$ & $\begin{array}{r}1 \\
2 \\
1 \\
1 \\
4 \\
2 \\
3 \\
7 \\
16 \\
3 \\
40\end{array}$ & $\begin{array}{c}1 \\
\\
1 \\
1 \\
1 \\
\\
1 \\
5 \\
45\end{array}$ & $\begin{array}{r}1 \\
2 \\
2 \\
1 \\
3 \\
2 \\
3 \\
5 \\
2 \\
5 \\
8 \\
2 \\
2 \\
36 \\
41\end{array}$ & $\begin{array}{l}1 \\
1 \\
1\end{array}$ \\
\hline
\end{tabular}

PPNG = penicillinase producing Neisseria gonorrhoeae. 
were cured. Of the 38 patients infected with nonPPNG strains whose MICs ranged from 0.00001 $\mathrm{mg} / \mathrm{l}$ to $0.03 \mathrm{mg} / \mathrm{l}, 34(89.5 \%)$ were cured.

\section{SIDE EFFECTS}

Of the 93 patients who received rosoxacin and came for follow up examination, $18(19 \cdot 4 \%)$ reported side effects: 17 had mild dizziness and one had generalized itching, but no clinical signs were seen on examination.

\section{POST GONOCOCCAL URETHRITIS (PGU)}

Of the 80 patients in group A (spectinomycin) who had more than one follow up examination, 33 $(41 \cdot 3 \%)$ had PGU. Of the 72 patients in group B (rosoxacin), $33(45 \cdot 8 \%)$ had PGU. There was no difference between the two groups $\alpha^{2}=0.32$; $\mathrm{p}>0.01)$.

\section{Discussion}

.In areas of the world where PPNG strains are highly prevalent the drugs that should be used in the treatment of gonococcal infections should be highly effective for both PPNG and non-PPNG strains. Apart from spectinomycin, many new cephalosporins (namely cefuroxime, cefotaxime, cefoxitine, and ceftriaxone) have been reported to be highly effective in the treatment of such infections. ${ }^{4518-26}$ The administration of these drugs requires intramuscular injection which is often painful. Rosoxacin is a drug that can be given by mouth in only two $300 \mathrm{mg}$ capsules. In this dosage the drug has been reported to be highly effective in the treatment of both PPNG and non-PPNG strains with cure rates from $94 \%$ to $100 \% .{ }^{27-31}$ The results of treatment of gonococcal infections with the same dosage in Thailand were different. Polnikorn et al ${ }^{32}$ reported a cure rate of $87.5 \%$ and in our study we had a $88.5 \%$ cure rate. The prevalence of PPNG strains in the study population of Polnikorn et al was $52 \%$, and in our patients it was $54 \%$.

The difference between the cure rates in group $\mathbf{A}$ (spectinomycin) and group B (rosoxacin) was significant $\left(\chi^{2}=9.89 ; p<0.01\right)$. In group B (rosoxacin) there was no difference between the results of treatment of the patients infected by PPNG and nonPPNG strains $\left(\chi^{2}=0.02 ; p>0.01\right)$.

The side effects encountered among the patients who took rosoxacin in our study were considered to be mild, and all the patients recovered spontaneously. We conclude that the tolerance to this antimicrobial agent was good.

The authors thank Sterling Drug International Inc of Thailand for providing the rosoxacin used in this study.

\section{References}

1. Siegel MS, Thompson SE, Perine PL. Penicillinase producing Neisseria gonorrhoeae. Sex Transm Dis 1977;4:32-3.

2. Panikabutra $K$, Suvannamalik S. Beta lactamase producing Neisseria gonorrhoeae in Bangkok: report of the first two cases. Journal of the Venereological Group of Thailand 1977; 1:24-30.

3. Panikabutra $\mathrm{K}$, Suvannamalik $\mathrm{S}$. Penicillinase producing $\boldsymbol{N}$ gonorrhoeae and its therapeutic aspects in Bangkok. Thailand. (Paper presented to the 30th General Assembly of IUVDT in East Berlin 6-12 June 1980). Journal of the Venereological Group of Thailand 1981;1:20-38.

4. Panikabutra K, Ariyarit Ch, Chitwarakorn A, Warnnissorn T, Saensanoh C. Sensitivity to penicillin, thiamphenicol, kanamycin, cefoxitin and spectinomycin of PPNG in Bangkok. Relation to the results of treatment. J Med Assoc Thai 1982; 65:316-24.

5. Panikabutra $\mathbf{K}$, Ariyarit $\mathrm{Ch}$, Chitwarakorn $\mathbf{A}$, Warnnissorn $\mathrm{T}$. Cefotaxime in the treatment of gonorrhoea caused by PPNG and Non PPNG. J Med Assoc Thai 1982;65:271-6.

6. Kaufman RE, Johnson RE, Jaffe HW, et al. National gonorrhoeae monitoring study: treatment results. $N$ Engl $J$ Med 1976; 294:1-4.

7. McCormack WM. Treatment of gonorrhoeae-is penicillin passé? N Engl J Med 1977; 296:934-6.

8. Centers for Disease Control. Gonorrhoeae recommended treatment schedules, 1979. MMWR 1979;28:13-21.

9. Adams H, Ashford W, Potts DW, San Diego A, Chong V, Grant D. Spectinomycin resistant penicilinase-producing Neisseria gonorrhoeae California. MMWR 1981;30:221-2.

10. Kim JH, Han GC, Hong SW, Junn JW. Spectinomycin resistant PPNG. Journal of the Korean Medical Association 1982; 25: $1117-20$.

11. Easmon CSF, Ison CA, Bellinger CM, Harris JW. Emergence of resistance after spectinomycin treatment for gonorrhoeae due to beta-lactamase producing strain of Neisseria gonorrhoeae. Br Med J 1982; 284:1604-5.

12. Patefield AJ, Westbrook WG, Johnston NA. Spectinomycin resistant Neisseria gonorrhoeae-worldwide. MMWR 1982;31:632, 637, 638.

13. Jones $O$, Strohmeyer G., Brockett J, et al. Spectinomycin resistant penicillinase-producing Neisseria gonorrhoeae. $M M W R$ 1983;32:51-2.

14. Seth AD. Sensitivity of gonococci to rosoxacin compared with that of penicillin, cefuroxime and tetracycline. J Antimicrob Chemother 1981;7:331-4.

15. World Health Organisation. Neisseria gonorrhoeae and gonococcal infections. Tech Rep Ser 1978; No 616: World Health 138-139.

16. Jaffe HW, Biddle JW, Thornsberry C, et al. National gonorrhoeae therapy monitoring study: in vitro antibiotic susceptibility and its correlation with treatment results. $N$ Engl J Med 1976; $294: 5-9$.

17. World Health Organisation Scientific Group. Non-gonococcal urethritis and other selected sexually transmitted diseases of public health importance. Tech Rep Ser 1981; No 660:59.

18. Tupasi TE, Crisologo LB, Torres CA, Calubiran OV, De Jesus I. Single dose alternative therapy for uncomplicated gonorrhoeae in women with special reference to beta-lactamase producing strains. WHO/VDT/80. 1980;424:1-12

19. Polnikorn N, Vorachit M, Puavilai S, Charuvichitratana S. The penicillinase producing Neisseria gonorrhoeae (PPNG) and treatment with cefuroxime. Ramathibodi Medical Journal $1981 ; 4: 234-8$.

20. Hard S, Moberg I, Wennberg K. Single dose treatment of gonococcal urethritis in males with cefotaxime in different concentrations. Asian Journal of Clinical Sciences 1980; 1:307-10.

21. Lancaster DJ, Berg SW, Harrison WO, Ockermann KO. Treatment of penicillin-resistant gonorrhoeae with cefotaxime. Drug Therapy 1981; suppl: 87-90.

22. Rajan VS, Sng EH, Pang R, Tan NJ, Thirumorrthy T, Yeo KL. HR 756-a new cephalosporin in the treatment of gonorrhoea caused by ordinary and penicillinase-producing strains of Neisseria gonorrhoeae. Br J Vener Dis 1980; 56:255-8.

23. Hansfield HH, Holmes KK. Treatment of uncomplicated gonorrhoea with cefotaxime. Sex Transm Dis 1981;8: 187-91.

24. Siegel MS, Thompson SD, Perine PL, Brown ST, Reynolds G, Thornsberry C. Treatment of uncomplicated ganococcal urethritis with cefoxitin: comparison with penicillin. Rev Infect Dis 1979; 1:183-7. 
25. Jones RB, Stimson J, Counts GW, Holmes KK. Cefoxitin in the treatment of gonorrhoea. Sex Transm Dis 1979;6:239-42.

26. Berg SW, Kilpatrick ME, Harrison WO, McCutchan JA. Cefoxitin as single dose treatment for urethritis caused by penicillinase producing $N$ gonorrhoeae. N Engl J Med 1979;301: 509-11.

27. Rajan VS, Sng EH, Thirumoorthy T, Goh CL. Ceftriaxone in the treatment of ordinary and penicillinase-producing strains of Neisseria gonorrhoeae. Br J Vener Dis 1982;58:314-6.

28. Woscoff A, Flichman JC, Man F, et al. Rosoxacin (Win 35, 213) in the treatment of uncomplicated acute gonococcal infection. Clinical Therapeutics 1981;4:515-25.
29. Soendjojo A, Hudiono H, Idajadi A, Barakbah Y. Rosoxacin, a new agent for the treatment of gonorrhoeae. Asian Journal of Clinical Sciences 1982;3:34-6.

30. Limson BM, Macasaet RK. Single oral dose rosoxacin in the treatment of gonorrhoeae in males. J Int Med Res 1982;10: 42-5.

31. Calubiran OV, Vizconde LB, Tupasi TE, Torres CA, Limson BM. Treatment of uncomplicated gonorrhoeae in women: comparison of rosoxacin and spectinomycin. Br J Vener Dis 1982; 58:231-5.

32. Polnikorn N, Charuwichitratana S, Puavilai S, Vorachit H. Treatment of acute gonorrhoea with oral rosoxacin in Thai patients. Ramathibodi Medical Journal 1983;2: 106-8. 